\title{
Exergy analysis of mass housing areas: Mavişehir I and II, Izmir
}

\section{Yelda Mert*}

Faculty of Engineering and Architecture, Department of City and Regional Planning, Yüzüncü Yıl University, Zeve Campus, Van TR-65080, Turkey

Email: mertyelda@gmail.com

${ }^{*}$ Corresponding author

\section{Nicel Saygın}

Faculty of Architecture,

Department of City and Regional Planning, Izmir Institute of Technology, Urla, İzmir TR-35100, Turkey

Email: nicelsaygin@iyte.edu.tr

\begin{abstract}
In this study, in terms of urban design, an exergy analysis of Mavişehir mass housing area in Izmir, Turkey is carried out based on spatial properties, shadow effects, wind effects and local climate to understand the importance of design strategies. The exergy analysis is applied with broad consideration covering the heat loads of the separate buildings for winter and summer. When the exergy results of Mavişehir I and Mavişehir II are compared it is found that Mavişehir II has less exergy by fuel and exergy load values. This may result from different design strategies in Mavișehir I where the same buildings and villas between residential buildings are located according to sea view, whereas in Mavişehir II, there is a heterogeneous pattern with various forms and heights of the residential buildings. It was also discovered that exergy efficiency of the area is $4.20 \%$ and the exergy flexibility factor is $19.3 \%$
\end{abstract}

Keywords: exergy; building block design; energy-efficient design; city planning.

Reference to this paper should be made as follows: Mert, Y. and Saygin, N. (2015) 'Exergy analysis of mass housing areas: Mavişehir I and II, Izmir', Int. J. Exergy, Vol. 17, No. 1, pp.17-34.

Biographical notes: Yelda Mert is an Assistant Professor in the Department of City and Regional Planning of Yüzüncü Y1l University. She received her BS, MS, and PhD from Department of City and Regional Planning of Izmir Institute of Technology in 2005, 2009, and 2014 respectively. Some of her research areas include energy-efficient planning and the role of planner.

Nicel Saygin is an Assistant Professor in the Department of City and Regional Planning of Izmir Institute of Technology. She received her BS in City and Regional Planning at Dokuz Eylül University, MS in City and Regional Planning at Clemson University, and $\mathrm{PhD}$ in Design and Planning at University 
of Colorado Denver. Some of her areas of interest include design and politics of public spaces, urban design, conservation of historic urban sites, and sustainable development.

This paper is a revised and expanded version of a paper entitled 'Exergy analysis of a residential area in terms of energy efficiency, case study: Mavişehir' presented at 6th International Ege Energy Symposium \& Exhibition, Izmir, Turkey, 28-30 June, 2012.

\section{Introduction}

It is wise to give importance to the energy used in cities to sustain domestic needs since almost $30 \%$ of the total energy consumption in the world arises from residential areas (Balocco et al., 2004). Moreover, increasing sensitivity to global warming and pressure to reduce energy consumption because of rising energy prices increases this importance. In addition to these facts, when the power of city planning on land-use decisions and applications are taken into consideration, it is easy to relate the energy consumption and sustainability to city planning. Besides, spatial planning evaluates the values/assets of the city and the region regarding preservation and land use.

New emerging habits of the populations in cities bring larger problems about energy and environment, such as air, water, and earth pollution. These problems cause some irreversible changes globally. For the solution to these problems, urban design and planning may play an important role. Design of urban areas may include ecological concerns, as well as clean renewable energy-oriented solutions.

Design of energy-efficient residential units, energy-efficient residential blocks, energy-efficient districts, and energy-efficient cities are important steps that have been taken for the sake of energy conservation. Therefore, it is crucial that energyeffectiveness must be taken into account starting from design of a single house up to the regional scale and all sub scales, regarding physical factors such as morphology, density, and microclimate properties. By considering energy-efficient design criteria in building block design, the energy efficiency citywide will be improved (Hisarligil, 2009).

The planning decision process in Turkey is mostly completed according to the profitability and luxury of the housing development. Most of the important parameters like protection of the environment, lighting, orientation, air flows, and use of renewable energy sources are neglected in many cases. There is legislation, but it is ineffective and insufficient for sustaining energy efficiency. Such legal guidelines are useless like the height of the building and road width relations in terms of climatic conditions. Some codes ignore local characteristics or some general rules such as the importance of orientation of buildings with respect to solar energy, especially important in a country like Turkey where there is vast opportunity to avail of solar energy. Therefore, the legal structure must be revised considering ecology and sustainability and national policies must have strict rules and auditing. To control the success and progress of each plan, some local commissions and governmental organisations must be formed, and these organisations must educate the people and decision-makers by preparing some guide books (Ercoşkun, 2007). In Turkey, since July 2000, with the implementation of the 
TS825 Heat Insulation legislation, the heating and cooling loads of buildings began to be calculated and taken into consideration in construction. However, this is not sufficient since to increase the energy efficiency and effectiveness in urban areas (besides the heating and cooling loads), the effect of orientation and microclimatic effects also have to be considered.

As an effective tool for identifying the energy consumption sources and the areas where the designer has to aim for better efficiency and effectiveness of energy usage, exergy analysis is the best option, as was pointed out in the investigation by Dinçer and Rosen (2007). Exergy analysis is used to analyse the true characteristics of the energy flow in a building block in this study. As being a method that reveals the quality of the energy by including the potential of an energy source considering the environment that it's presently in, exergy analysis brings the investigator the chance to see the true potential of an energy source and energy system. Exergy is the quality and the potential of energy that can be transferred to work. The potential work loses when the change of the state defines an exergy loss. During a state change the decrease in the loss of exergy directly increases the production rates. For this reason, performance of the system can be maximised by minimising exergy losses. In this context, exergy analysis helps to identify and locate the energy loss points of a system for sake of increasing efficiency and cost reduction as well as decreasing emission. Moreover, the analysis is used in the design, optimisation, and development of the energy related systems. It can also be said that the efficiency in terms of exergy represents the distance between real performance and ideal performance of a system (Dinçer and Rosen, 2007).

Since the residential areas are one of the most energy-consuming sectors any improvement in the energy profile will greatly contribute to the global energy system. On behalf of these, applying the exergy analysis on urban systems becomes mandatory for the sake of efficient and sustainable settlements.

There are various studies in the literature on a global scale about energy efficiency and effectiveness of heating, cooling, lighting, and transportation sectors including buildings. However, there are no studies in the literature about the energy (exergy) effectiveness and efficiency which cover a residential area or residential pattern completely including the form and relation of buildings with each other.

When the literature is examined, there are few studies about these considerations with a comprehensive aspect. There are some studies on only exergy and/or energy analyses of buildings, like the studies by Balta et al. (2011), Depecker et al. (2001), Koroneos and Kalemakis (2012), Tronchin and Fabbri (2008), Sakulpipatsin et al. (2008), Hepbaşlı (2012), and Schmidt (2012) in which different energy sources for a building and the effect of shape on energy consumption were investigated using exergy analysis and for various reference conditions. Most of them focussed on the calculation of the energy consumption of the buildings. Another study (Barreiro et al., 2009) investigates the energy efficiency of an area and proposes an integrated energy supply methodology that examines the relations between planning and efficiency. Meggers and Lejbundgut (2012) studied the utilisation of exergy and energy concepts for low exergy system design in the search for a better performance by buildings. In some studies the exergy analysis is used to investigate the urban area, as pointed out in Utlu and Hepbaşlı, (2005, 2007), Schmidt (2004), Ozturk et al. (2004), Liu et al. (2010) and Balocco et al. (2004). 
Energy-effective planning and design decisions affect, and are important for, regional-scale decisions as the Institute of Energy of Turkey pointed out (EIE, 2014). Different properties of the spatial structure at different scales are important in terms of the energy-effectiveness. At micro scales, direct forward changes bring considerable improvements, such as adjusting proper orientation for the sake of energy saving, without causing extra cost to the construction. Physical structure of the settlement, altitude, and closeness to the sea directly affect microclimates, since the land can absorb and desorb heat at a faster rate than a body of water and the altitude directly affects the climate. The combination, location, and texture that the houses form affect the climate on a regional basis, in addition to the orientation, geometric and physical properties. Moreover, the density of the structures and building blocks, especially dense and high buildings, affect the climate greatly in urban areas. Geometric shapes and distances between buildings and other structures affect the wind direction and speed as well as the air temperature. The wind speed is important since it affects the heat transfer mechanism and increases the heating loads of the structures in winter and cooling loads in summer.

Depending on all of these parameters, physical properties such as the orientation and geometry as well as the texture of the settlement, are significant in terms of the energy efficiency, since they affect the microclimate in the urban area.

In this study two different stages of the Mavişehir mass housing area are examined from an exergetic point of view with the aim of informing planners and researchers about the importance of the energy/exergy concerns in the decision-making phase of a design process. In order to reach the main exergy loss points of a building and the residential area, the effects of orientation, shadowing, insulation, and heating systems are considered in this study. Besides, a parameter is introduced to the literature that is shadow effect factor (SEF) which is an indication of shadowing period of the building because of improper spacing and orientation.

\section{Case study}

Mavişehir is located at the boundary of Karşıyaka Municipality, north of İzmir Bay (Figure 1(a)). The region is defined as high-rise blocks of a mass housing area according to the Metropolitan Master Plan of İzmir. The area, total 270 ha, is surrounded by Atakent housing units to the east, by the old Gediz river bed to the west, by a slum housing area to the northeast, by İzmir-Manisa-Ankara railway yard to the north, and by İzmir Bay to the south. Mavişehir mass housing area is formed by three regions that were constructed in three stages by subsidies of the Housing Credit Bank (Koç, 2001; Aydoğan, 2005).

Construction of Mavişehir Stage-I began in 1993 and was completed in two years. Mavişehir-I has two urban areas with $260.000 \mathrm{~m}^{2}$, separated by a water canal: 12 highrises in the western part, which are called Pamukkale, and eight high-rises in the eastern part, which are called Selçuk (Figure 1(b)). In total, there are 20 residential high-rise buildings (2784 flats) and 88 duplex villas located in between the residential high-rises. Three of the residential high-rises have 16 stories, 10 of them have 18 stories, and seven of them have 19 stories (Figure 2). Each story has 8 flats. In total Mavișehir I consists of 2872 housing units with net area between $58 \mathrm{~m}^{2}-150 \mathrm{~m}^{2}$ with $1,2,3,4$ rooms. The project has a density of 174 houses/ha and net population density of 664 person/ha (Koç, 2001). The aim is that every apartment will have a sea view, and that fresh air coming 
from the sea is not blocked by adjusting the blocks perpendicular to the coast. On the other hand, the duplex villas that have been positioned between the rectangular blocks are caught between them and have some difficulty with visual privacy (Sayar and Süer, 2004). Moreover, the villas have a significant shadow problem because of the high-rise blocks adjacent to them.

Figure 1 (a) Location of Mavişehir in İzmir Bay (Izmir City Guide) and (b) Location of the investigated case (İzmir City Guide)
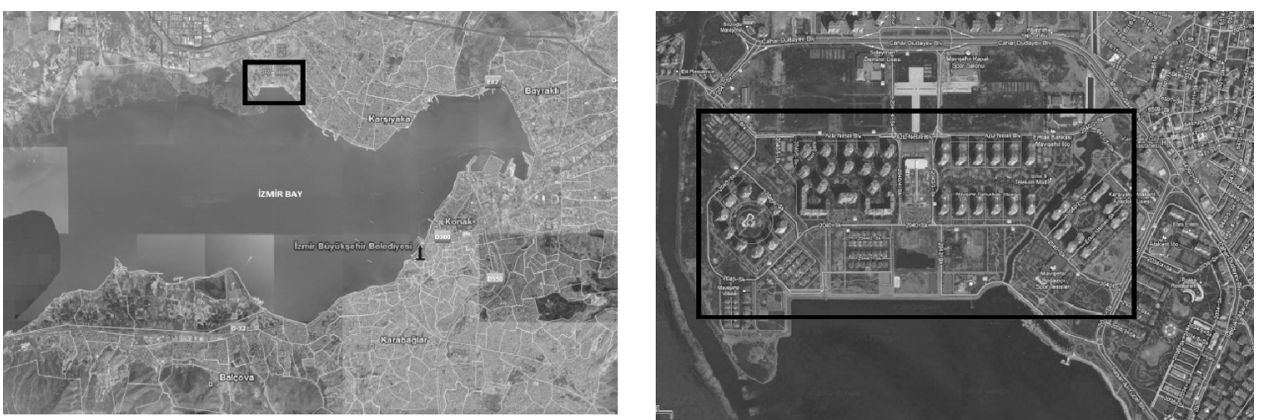

Figure 2 Plan of Mavişehir (Karşıyaka Municipality) (see online version for colours)

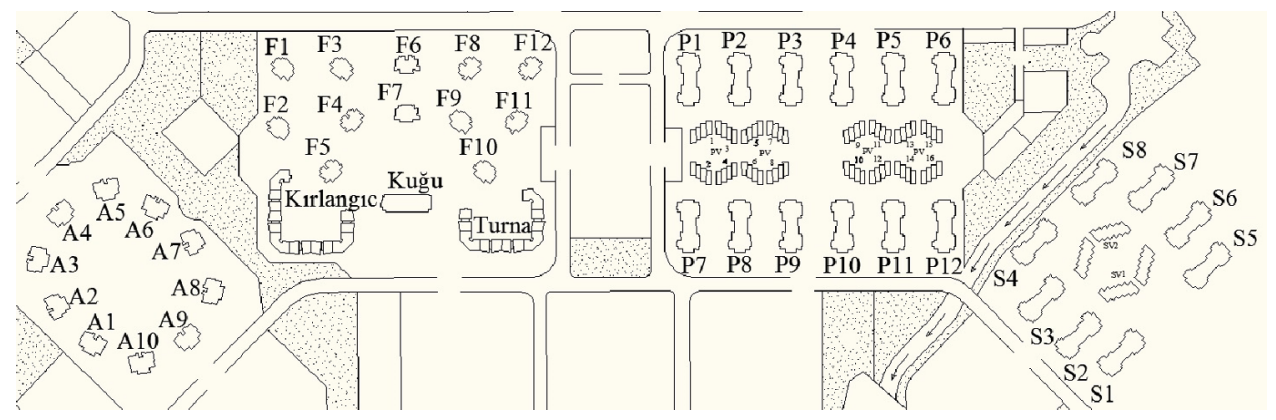

Differing from Mavişehir I, Mavişehir II has different types of high-rise blocks. Various designs and combinations of the high-rises provide the built environment with dynamism. The total area of case study is $512.803 \mathrm{~m}^{2}$. The construction of the stage was started in 1995 and was completed in 1997. In total there are 2448 residential units with net area between $56 \mathrm{~m}^{2}-149 \mathrm{~m}^{2}$ and 1, 2, 3, 4 rooms in 38 residential high-rises. The names of high-rises are Albatros, Flamingo, Kuğu, Kırlangıç, and Turna. Albatros consists of 10 high-rises with 22 stories. Flamingo blocks are 12 blocks, each of which is a 23 -story building. Only Kuğu housing block has 22 stories. Turna, on the other hand, is a combination of seven different plan types with 10 and 14 stories. Similarly Kırlangıç is a combination of eight different plan types of 10 and 14 stories (Aydoğan, 2005).

Mavişehir III is located by the sea with 122 triplex villas. The study concerns the first and second stages of Mavişehir area. Every accommodation in the area can be assumed to be a luxury residential high-rise with central heating system, double glazing, sun blinds, decorative coated doors, and double bathrooms (Aydoğan, 2005).

The heating system in Mavişehir is a central heating system with a condensing boiler fired with natural gas. Heat is distributed through the housing units with using 
heat pay meter. Radiators are used to distribute the heat in the housing unit. For the cooling, separate split-type air conditioners are used in the housing units.

\section{Exergy analysis of a residential area}

Calculations for the exergy load of urban areas are complicated and start with data handling which covers five major data types as follows:

- $\quad$ size of the buildings

- $\quad$ insulation of the buildings

- $\quad$ orientation of the buildings

- resident information

- $\quad$ heating system properties.

After completing the data handling, the following exergy calculations take place:

- $\quad$ calculation of the shadow effect factor (SEF)

- calculation of the exergy load of each building for heating and cooling

- calculation of the exergy loads for the building block heating and cooling.

SEF is an indication of a building's blockage by the shadow of another building, which is the effect of the overlapping shadow on the building behind one another (Mert, 2014).

Some assumptions that will be applied for the analysis include the following:

- $\quad$ indoor air temperature of $21^{\circ} \mathrm{C}$.

- $\quad$ outdoor temperature is taken as $10.9^{\circ} \mathrm{C}$ as the average winter temperature for Izmir (between the years of 1960-2012) (MGM, 2012)

- the heat transfer coefficients of the walls and doors are taken from the real values depending on the plan details of the buildings which were obtained from Karşıyaka Municipality, depending on data reported by the construction company.

- the average number of the residents is assumed to be 4 during the calculations

- $70^{\circ} / 50^{\circ}$ heating system (inlet/outlet temperature of the radiators) is used in calculations in accordance with reality.

- $\quad$ split air conditioners are used with COP value of 3 in cooling calculations.

The aim of the calculation procedure is to calculate the $\dot{E} x_{\text {demand }}$ values which show us the exergy need of the building calculated using the assumptions given above. For the calculation of exergy demand, the procedure proposed by LowEx (2012) is utilised.

$$
\dot{E} x_{\text {demand }}=\dot{E} x_{\text {loss }}-\dot{E} x_{\text {gain }} \text {. }
$$

$\dot{E} x_{\text {loss }}$ is calculated by the transmission losses through the doors, walls, windows, and roofs.

$$
\dot{E} x_{\text {loss }}=\dot{E} x_{\text {loss,transmisson }}+\dot{E} x_{\text {loss,ventillation }}
$$




$$
\dot{E} x_{\text {loss,transmisson }}=\sum U_{i} \cdot A_{i} \cdot\left(T_{i}-T_{o}\right) .
$$

Exergy loss by transmission is calculated by considering the heat transfer coefficient of walls, doors, roofs and ceilings $\left(U_{i}\right)$ as well as the areas $\left(A_{i}\right)$ and the indoor $\left(T_{i}\right)$ and exterior $\left(T_{o}\right)$ air temperature difference.

$$
\dot{E} x_{\text {loss,ventillation }}=C p \cdot \rho \cdot V \cdot n_{d} \cdot\left(1-n_{v}\right) \cdot\left(T_{i}-T_{o}\right)
$$

where $\rho$ and $C_{p}$ is the density $\left[\mathrm{kg} / \mathrm{m}^{3}\right]$ and specific heat $[\mathrm{kJ} / \mathrm{kgK}]$ of air, respectively. $n_{d}$ and $n_{v}$ are the air exchange rate $[\mathrm{ach} / \mathrm{h}]$ and efficiency constants, respectively.

$\dot{E} x_{\text {gain }}$ is a result of solar heat gains through windows which is a function of SEF. Also other gains that arise from auxiliary equipment in the houses are taken into consideration such as lighting $\left(2 \mathrm{~W} / \mathrm{m}^{2}\right)$.

$$
\begin{aligned}
& \dot{E} x_{\text {gain }}=\dot{E} x_{\text {gain,solar }}+\dot{E} x_{\text {gain,internal }} \\
& \dot{E} x_{\text {gain,solar }}=I_{s} \cdot\left(\frac{100-\mathrm{SEF}}{100}\right) \cdot\left(1-F_{f}\right) \cdot A_{w} * g .
\end{aligned}
$$

$I_{s}$ is the solar radiation $\left[\mathrm{W} / \mathrm{m}^{2}\right], F_{f}$ is window frame fraction taken as $0.3, A_{w}$ is the window area $\left[\mathrm{m}^{2}\right]$, and $g$ is the total transmittance.

$$
\mathrm{SEF}=\left(\frac{t_{\text {shadow }}}{t_{\text {daytime }}} \times 100\right) .
$$

SEF is calculated by determining the ratio of the shadowed time $\left(t_{\text {shadow }},[\mathrm{min}]\right)$ of the building to the daytime $\left(t_{\text {daytime }},[\mathrm{min}]\right)$ with direct sunlight access in an approximate manner by using the 3D model of the area.

$$
\dot{E} x_{\text {gain,internal }}=n_{o} \cdot \varphi_{i, o}+A_{N} \cdot \varphi_{i, e}
$$

where $n_{o}$ is the number of occupants, $A_{N}$ is the floor area of the building $\left[\mathrm{m}^{2}\right], \Phi_{I, o}$ and $\Phi_{I, e}$ are specific internal gains of occupants [W/occupant] and specific internal gains of equipment $\left[\mathrm{W} / \mathrm{m}^{2}\right]$, respectively.

$\dot{E} x_{\text {input }}$ is calculated depending on the $\dot{E} x_{\text {demand }}$ by considering the efficiency of the heat production and heat distribution systems which are 0.95 and 0.93 , respectively.

EFF is calculated by equation (9), which is an indication of the possibility of replacing a given system by another to meet the exergy demand.

$$
\begin{aligned}
& \mathrm{EFF}=\frac{\dot{E} x_{\text {demand }}}{\dot{E} x_{\text {input }}} \\
& \dot{E} x_{\text {input }}=\frac{\dot{E} x_{\text {demand }}}{\eta_{\text {heat_sys }}}+\dot{E} x_{\text {loss }}+\dot{E} x_{\text {axu }} .
\end{aligned}
$$

The calculation of the exergy input term depends on the efficiency of the heating system, the loss in the distribution system, and the auxiliary exergy need of the devices in the building and area. 
Exergy load of the buildings defines the amount of exergy needed by the building including the passive solar effects and the effects of the surroundings. On the other hand, the exergy by fuel is the definition of the amount of fuel exergy that must be supplied to the building.

The calculations of the cooling loads are based on the heat gain of the buildings from environment and solar energy during summer time with an average temperature value of $26.8^{\circ} \mathrm{C}$ (MGM, 2012).

$$
\dot{E} x_{\text {cooling }}=E x_{\text {axu }}+\dot{E} x_{\text {gain,solar }}+\dot{E} x_{\text {gain,transmisson }} .
$$

In the calculations, the first and second stages of Mavişehir area were examined. In accordance with the calculation algorithm first the size and various properties of the buildings and the area are gathered and tabulated in Table 1.

Table 1 The data surface area of the buildings

\begin{tabular}{lccccc}
\hline Building & $\begin{array}{c}\text { Exterior wall } \\
{\left[\mathrm{m}^{2}\right]}\end{array}$ & Window $\left[\mathrm{m}^{2}\right]$ & Door $\left[\mathrm{m}^{2}\right]$ & Roof $\left[\mathrm{m}^{2}\right]$ & $\begin{array}{c}\text { Floors to } \\
\text { ground }\left[\mathrm{m}^{2}\right]\end{array}$ \\
\hline Albatros & 7832 & 822 & 602 & 667 & 667 \\
Flamingo & 4235 & 504 & 726 & 594 & 594 \\
Kuğu & 10003 & 1306 & 1309 & 1044 & 1044 \\
Kırlangıç & 18554 & 2378 & 1584 & 2793 & 2793 \\
Turna & 18554 & 2378 & 1584 & 2793 & 2793 \\
Selçuk & 7239 & 1463 & 1178 & 1312 & 1312 \\
Pamukkale & 7239 & 1463 & 1178 & 1312 & 1312 \\
Villa Selçuk & 1493 & 135.72 & 109.68 & 1200 & 1200 \\
Villa Pamukkale & 1493 & 135.72 & 109.68 & 1200 & 1200 \\
\hline
\end{tabular}

For the calculation of the SEF, 3-D models were developed and the previews for the summer and winter periods for selected times were generated. The 3-D model covers the modelling of the area by developing a model using the existing situation of the case with exact measures. The model lets us to simulate the time-depended effect of the sunlight regarding the attitude of the case are. By this the shadow properties of the buildings and the area can easily be seen in the outcomes of the 3-D model. The calculation of the SEF depends on the $t_{\text {shadow }}$ that is the time that building spends under the shadow of another building. In order to calculate this, a daily animation was created separately for each block group that lets us to investigate the shadowing through the buildings. The SEFs are determined according to these visuals, and the results are tabulated in Table 2 and shown in Figure 3.

Determination of the facades of the buildings in order to calculate the passive solar effect is very important. It shows the effect of the orientation on the energy and exergy performance of the buildings. Every building in the area was evaluated separately and the facades that face southwest to southeast and northwest to northeast are calculated and taken into consideration correspondingly. The data for these values are also shown in Table 2 . 
Table 2 Data for SEF and the lateral areas with respect to the orientation

\begin{tabular}{|c|c|c|c|c|}
\hline$\overline{\text { Building }}$ & South area $\left[\mathrm{m}^{2}\right]$ & North area $\left[\mathrm{m}^{2}\right]$ & Other area $\left[\mathrm{m}^{2}\right]$ & $S E F[-]$ \\
\hline A1 & 285.8 & 358.3 & 178.6 & 0 \\
\hline $\mathrm{A} 2$ & 285.8 & 358.3 & 821.7 & 5 \\
\hline A3 & 408.1 & 250.1 & 57.4 & 8 \\
\hline A4 & 321.6 & 214.4 & 286.9 & 30 \\
\hline A5 & 357.3 & 465.5 & 0.0 & 30 \\
\hline A6 & 285.8 & 429.8 & 107.2 & 8 \\
\hline A7 & 285.8 & 358.3 & 821.7 & 5 \\
\hline A8 & 408.1 & 250.1 & 57.4 & 35 \\
\hline A9 & 321.6 & 214.4 & 286.9 & 5 \\
\hline A10 & 357.3 & 465.5 & 0.0 & 3 \\
\hline $\mathrm{F} 1$ & 170.0 & 107.3 & 277.2 & 8 \\
\hline $\mathrm{F} 2$ & 154.5 & 97.5 & 252.0 & 8 \\
\hline F3 & 170.0 & 107.3 & 277.2 & 10 \\
\hline $\mathrm{F} 4$ & 170.0 & 107.3 & 277.2 & 10 \\
\hline F5 & 170.0 & 107.3 & 277.2 & 5 \\
\hline F6 & 192.0 & 78.0 & 234.0 & 20 \\
\hline F7 & 211.2 & 85.8 & 257.4 & 8 \\
\hline F8 & 170.0 & 107.3 & 277.2 & 10 \\
\hline F9 & 170.0 & 107.3 & 277.2 & 8 \\
\hline F10 & 170.0 & 107.3 & 277.2 & 5 \\
\hline F11 & 154.5 & 97.5 & 252.0 & 5 \\
\hline F12 & 170.0 & 107.3 & 277.2 & 3 \\
\hline Kırlangıç & 1062.3 & 548.0 & 768.6 & 3 \\
\hline Turna & 938.0 & 117.4 & 577.9 & 3 \\
\hline Kuğu & 407.9 & 407.9 & 491.0 & 3 \\
\hline $\mathrm{P} 1$ & 862.4 & 862.4 & 1267.2 & 3 \\
\hline P2 & 862.4 & 862.4 & 1267.2 & 3 \\
\hline P3 & 862.4 & 862.4 & 1267.2 & 5 \\
\hline P4 & 862.4 & 862.4 & 1267.2 & 5 \\
\hline P5 & 862.4 & 862.4 & 1267.2 & 5 \\
\hline P6 & 862.4 & 862.4 & 1267.2 & 5 \\
\hline P7 & 862.4 & 862.4 & 1267.2 & 0 \\
\hline P8 & 862.4 & 862.4 & 1267.2 & 3 \\
\hline P9 & 862.4 & 862.4 & 1267.2 & 3 \\
\hline P10 & 862.4 & 862.4 & 1267.2 & 3 \\
\hline P11 & 862.4 & 862.4 & 1267.2 & 3 \\
\hline P12 & 862.4 & 862.4 & 1267.2 & 3 \\
\hline PV1 & 61 & 61 & 0 & 50 \\
\hline
\end{tabular}


Table 2 Data for SEF and the lateral areas with respect to the orientation (continued)

\begin{tabular}{|c|c|c|c|c|}
\hline Building & South area $\left[\mathrm{m}^{2}\right]$ & North area $\left[\mathrm{m}^{2}\right]$ & Other area $\left[\mathrm{m}^{2}\right]$ & $S E F[-]$ \\
\hline PV2 & 61 & 61 & 0 & 50 \\
\hline PV3 & 61 & 61 & 0 & 70 \\
\hline PV4 & 61 & 61 & 0 & 80 \\
\hline PV5 & 61 & 61 & 0 & 80 \\
\hline PV6 & 61 & 61 & 0 & 80 \\
\hline PV7 & 61 & 61 & 0 & 75 \\
\hline PV8 & 61 & 61 & 0 & 70 \\
\hline PV9 & 61 & 61 & 0 & 60 \\
\hline PV10 & 61 & 61 & 0 & 60 \\
\hline PV11 & 61 & 61 & 0 & 75 \\
\hline PV12 & 61 & 61 & 0 & 80 \\
\hline PV13 & 61 & 61 & 0 & 80 \\
\hline PV14 & 61 & 61 & 0 & 80 \\
\hline PV15 & 61 & 61 & 0 & 70 \\
\hline PV16 & 61 & 61 & 0 & 60 \\
\hline S1 & 665 & 665 & 1292 & 0 \\
\hline $\mathrm{S} 2$ & 665 & 665 & 1292 & 10 \\
\hline S3 & 665 & 665 & 1292 & 30 \\
\hline S4 & 665 & 665 & 1292 & 20 \\
\hline S5 & 665 & 665 & 1292 & 0 \\
\hline S6 & 665 & 665 & 1292 & 10 \\
\hline S7 & 665 & 665 & 1292 & 30 \\
\hline S8 & 665 & 665 & 1292 & 20 \\
\hline SV1 & 20 & 13 & 33 & 50 \\
\hline SV2 & 20 & 13 & 33 & 60 \\
\hline
\end{tabular}

Figure 3 The computer model of Mavişehir I-II (see online version for colours)

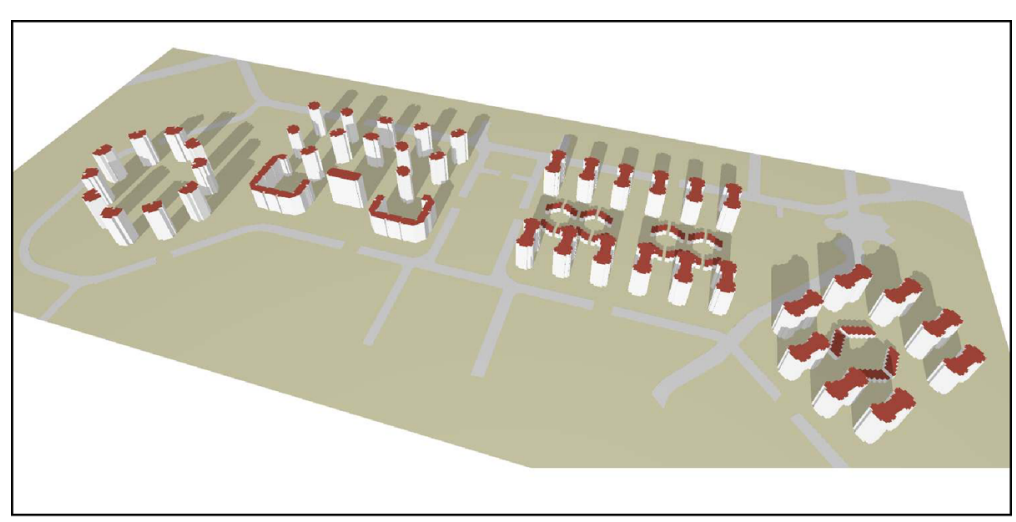


Figure 3 The computer model of Mavişehir I-II (see online version for colours) (continued)
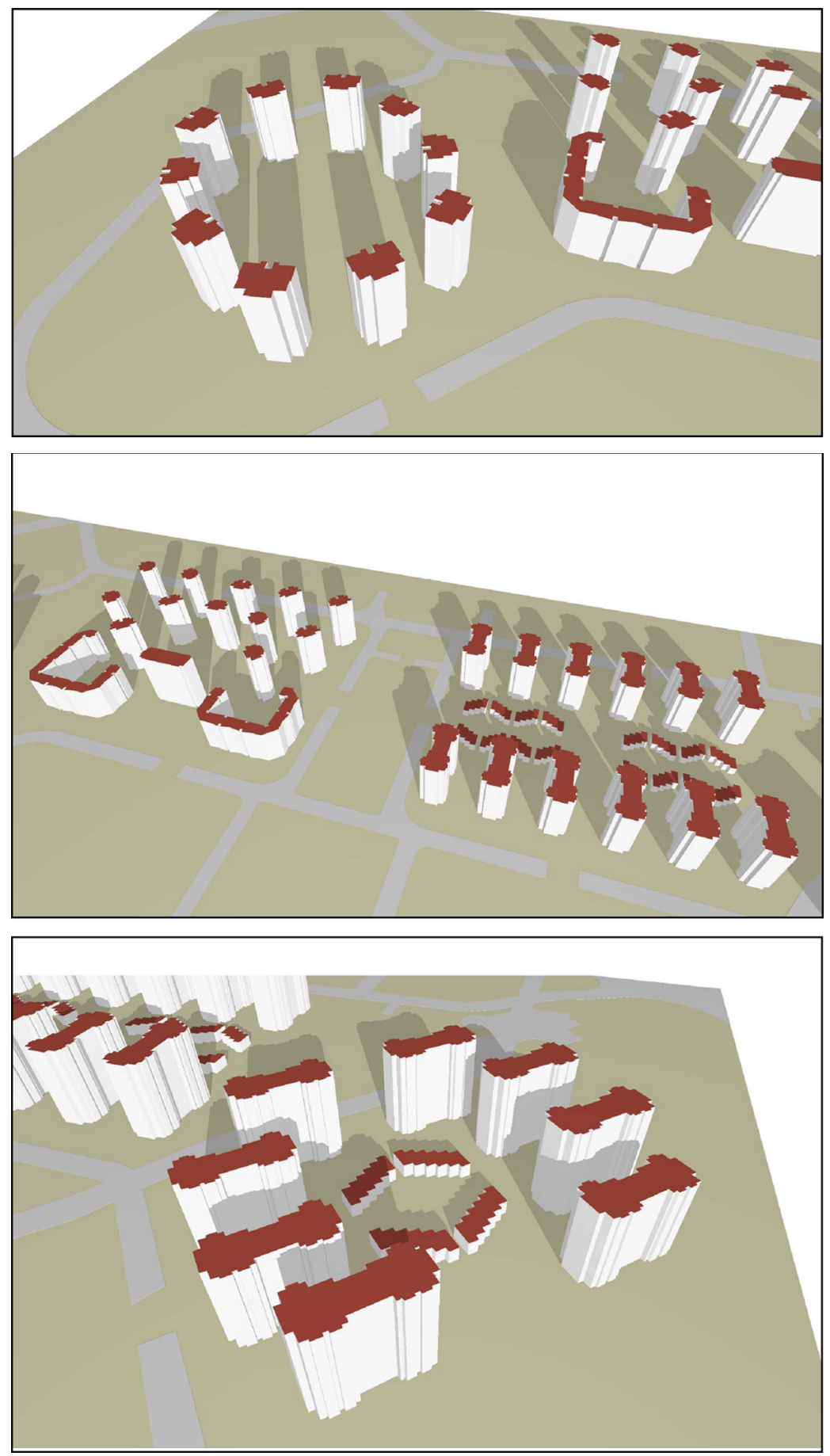


\section{Results and discussion}

Results of the analyses are demonstrated in Table 3 by the values of the exergy load, exergy by fuel, exergy efficiency, and EFF (Figure 4).

Table 3 Results for the exergy analysis

\begin{tabular}{|c|c|c|c|c|c|}
\hline Building & $\begin{array}{l}\text { Exergy load } \\
\text { summer }[\mathrm{W}]\end{array}$ & $\begin{array}{c}\text { Exergy load } \\
\text { winter }[\mathrm{W}]\end{array}$ & $\begin{array}{c}\text { Exergy by fuel } \\
\text { [W] }\end{array}$ & $\begin{array}{c}\text { Exergy } \\
\text { efficiency }[\%]\end{array}$ & $\begin{array}{c}\text { Exergy } \\
\text { flexibility } \\
\text { factor }[\%]\end{array}$ \\
\hline A1 & 314496 & 195584 & 131696 & 1.8285 & 13.792 \\
\hline A2 & 314090 & 195734 & 131810 & 1.8289 & 13.795 \\
\hline A3 & 313749 & 195860 & 131907 & 1.8292 & 13.797 \\
\hline A4 & 312986 & 196141 & 132123 & 1.8300 & 13.803 \\
\hline A5 & 312986 & 196630 & 132497 & 1.8312 & 13.812 \\
\hline A6 & 313749 & 195972 & 131993 & 1.8295 & 13.800 \\
\hline A7 & 314090 & 191697 & 128718 & 1.8185 & 13.716 \\
\hline A8 & 310625 & 197012 & 132790 & 1.8322 & 13.819 \\
\hline A9 & 314090 & 195300 & 131478 & 1.8278 & 13.787 \\
\hline A10 & 314396 & 195621 & 131724 & 1.8286 & 13.793 \\
\hline $\mathrm{F} 1$ & 212335 & 129326 & 82919 & 1.6558 & 12.489 \\
\hline $\mathrm{F} 2$ & 212335 & 117995 & 75632 & 1.6549 & 12.482 \\
\hline F3 & 211979 & 129190 & 82814 & 1.6551 & 12.484 \\
\hline $\mathrm{F} 4$ & 211979 & 129190 & 82814 & 1.6551 & 12.484 \\
\hline F5 & 212220 & 129101 & 82746 & 1.6546 & 12.480 \\
\hline F6 & 194034 & 118065 & 75686 & 1.6553 & 12.485 \\
\hline F7 & 212335 & 117464 & 75225 & 1.6518 & 12.459 \\
\hline F8 & 211979 & 129190 & 82814 & 1.6551 & 12.484 \\
\hline F9 & 212335 & 129155 & 82787 & 1.6549 & 12.482 \\
\hline F10 & 212220 & 129101 & 82746 & 1.6546 & 12.480 \\
\hline F11 & 212220 & 114164 & 72697 & 1.6323 & 12.312 \\
\hline F12 & 212316 & 129066 & 82719 & 1.6544 & 12.479 \\
\hline Kırlangıç & 765074 & 379890 & 284668 & 2.2369 & 16.872 \\
\hline Turna & 753556 & 384140 & 287923 & 2.2378 & 16.879 \\
\hline Kuğu & 426708 & 190935 & 130924 & 1.8950 & 14.293 \\
\hline P1 & 400207 & 221314 & 136360 & 1.5209 & 11.472 \\
\hline P2 & 400207 & 218908 & 136173 & 1.5527 & 11.712 \\
\hline P3 & 398288 & 219089 & 136311 & 1.5534 & 11.717 \\
\hline P4 & 398288 & 219089 & 136311 & 1.5534 & 11.717 \\
\hline P5 & 398288 & 219089 & 136311 & 1.5534 & 11.717 \\
\hline P6 & 398288 & 221495 & 136498 & 1.5216 & 11.477 \\
\hline P7 & 399510 & 218638 & 135965 & 1.5518 & 11.705 \\
\hline P8 & 400207 & 218908 & 136173 & 1.5527 & 11.712 \\
\hline
\end{tabular}


Table 3 Results for the exergy analysis (continued)

\begin{tabular}{|c|c|c|c|c|c|}
\hline Building & $\begin{array}{l}\text { Exergy load } \\
\text { summer [W] }\end{array}$ & $\begin{array}{c}\text { Exergy load } \\
\text { winter }[\mathrm{W}]\end{array}$ & $\begin{array}{c}\text { Exergy by fuel } \\
\text { [W] }\end{array}$ & $\begin{array}{c}\text { Exergy } \\
\text { efficiency }[\%]\end{array}$ & $\begin{array}{c}\text { Exergy } \\
\text { flexibility } \\
\text { factor }[\%]\end{array}$ \\
\hline P9 & 400207 & 218908 & 136173 & 1.5527 & 11.712 \\
\hline P10 & 400207 & 218908 & 136173 & 1.5527 & 11.712 \\
\hline P11 & 400207 & 218908 & 136173 & 1.5527 & 11.712 \\
\hline P12 & 400207 & 218908 & 136173 & 1.5527 & 11.712 \\
\hline PV1 & 83227 & 44466 & 30841 & 1.9392 & 14.627 \\
\hline PV2 & 83227 & 44466 & 30841 & 1.9392 & 14.627 \\
\hline PV3 & 82882 & 44594 & 30939 & 1.9403 & 14.635 \\
\hline PV4 & 82709 & 44658 & 30988 & 1.9409 & 14.640 \\
\hline PV5 & 82709 & 44658 & 30988 & 1.9409 & 14.640 \\
\hline PV6 & 82709 & 44658 & 30988 & 1.9409 & 14.640 \\
\hline PV7 & 82795 & 44626 & 30963 & 1.9406 & 14.637 \\
\hline PV8 & 82882 & 44594 & 30939 & 1.9403 & 14.635 \\
\hline PV9 & 83054 & 44530 & 30890 & 1.9398 & 14.631 \\
\hline PV10 & 83054 & 44530 & 30890 & 1.9398 & 14.631 \\
\hline PV11 & 82795 & 44626 & 30963 & 1.9406 & 14.637 \\
\hline PV12 & 82709 & 44658 & 30988 & 1.9409 & 14.640 \\
\hline PV13 & 82709 & 44658 & 30988 & 1.9409 & 14.640 \\
\hline PV14 & 82709 & 44658 & 30988 & 1.9409 & 14.640 \\
\hline PV15 & 82882 & 44594 & 30939 & 1.9403 & 14.635 \\
\hline PV16 & 83054 & 44530 & 30890 & 1.9398 & 14.631 \\
\hline S1 & 393547 & 223772 & 138243 & 1.5298 & 11.539 \\
\hline S2 & 387371 & 217249 & 138213 & 1.6288 & 12.285 \\
\hline S3 & 383600 & 218641 & 139279 & 1.6332 & 12.319 \\
\hline S4 & 389776 & 225163 & 139309 & 1.5347 & 11.576 \\
\hline S5 & 393547 & 216554 & 137680 & 1.6265 & 12.268 \\
\hline S6 & 387371 & 224468 & 138776 & 1.5322 & 11.557 \\
\hline S7 & 383600 & 225859 & 139842 & 1.5371 & 11.594 \\
\hline S8 & 389776 & 225163 & 139309 & 1.5347 & 11.576 \\
\hline SV1 & 43175 & 16338 & 10177 & 1.5633 & 11.791 \\
\hline SV2 & 43118 & 16359 & 10193 & 1.5643 & 11.799 \\
\hline
\end{tabular}

The insulation properties, passive heating with solar energy properties, windowing and orientation properties, and total facades of each building are taken into account in the exergy analysis.

In Table 3 it is seen that the efficiency values are around $1.5-2 \%$ which is an expected value since a natural gas-fired heater is used for the domestic heating system and when the factors of heat transmission, heat loss, and exergy destruction in the 
combustion process are taken into consideration. Also the cooling systems are integrated using split-type air conditioners. These values are in accordance with the literature and were expected (Schmidt, 2012). It is seen that the small efficiency values rely on buildings with bad orientation and SEF values Which causes a block on the solar radiation reaching to the buildings and decreases the solar gain favours an increase in heat loads in winter. On the other hand, decrease in solar radiation also positively inceases the cooling loads. That can be seen in the cooling loads in Table 3 when the SEF are considered. Moreover, the exergy loads of those buildings are considerably higher than the better-oriented and low SEF-valued buildings.

Figure 4 Exergy by fuel values of various buildings in the case-area (see online version for colours)
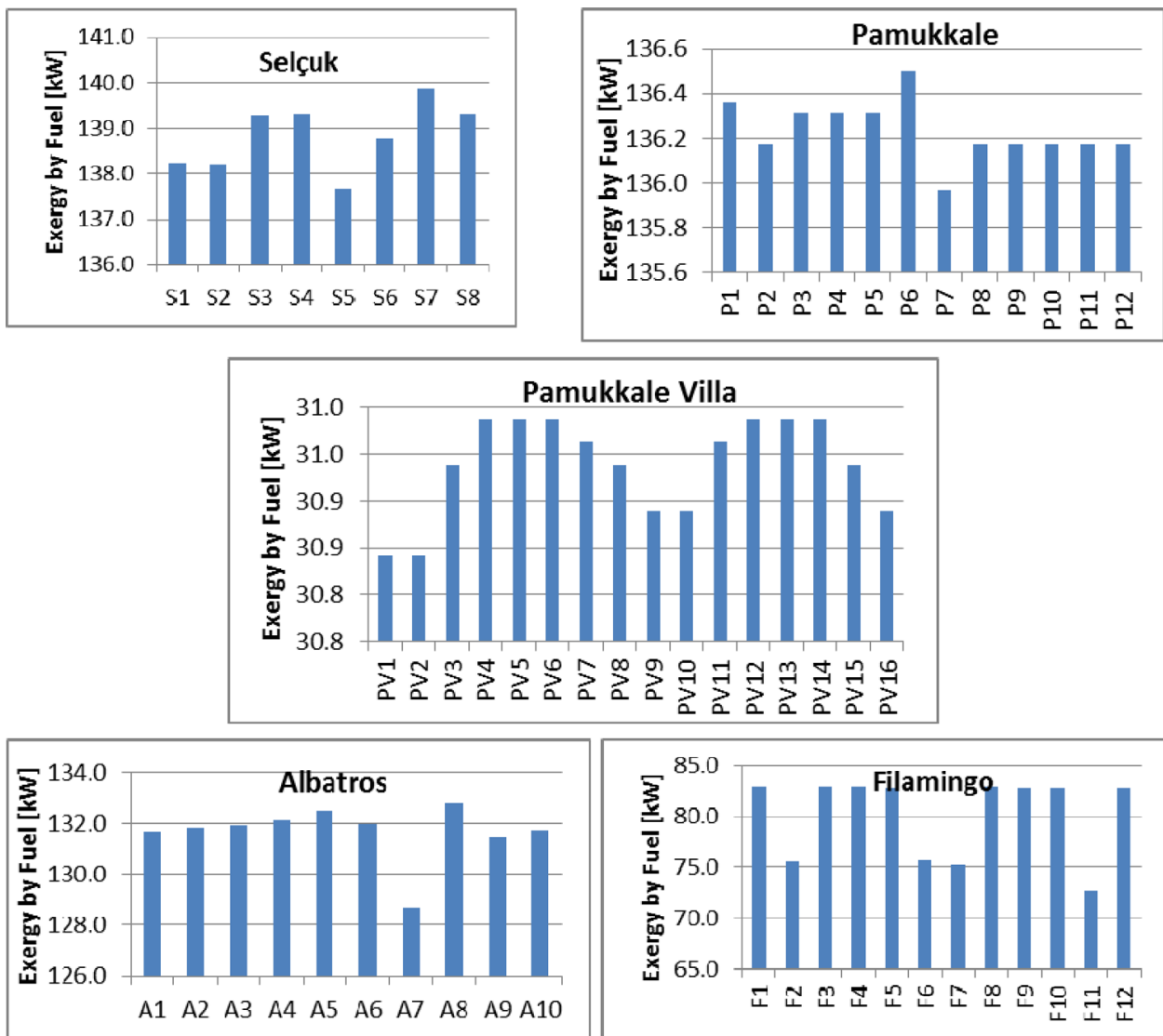

The EFFs of the urban area are around $11-15 \%$. This indicates that any replacement in the system will clearly increase the efficiency and support effective and renewable energy systems such as usage of solar power, fuel cells, or wind energy. These replacements have to be considered when the sustainability of the cities and neighbourhoods are taken into account for an energy-effective and liveable urban area. 
Table 4 demonstrates the total heating and cooling exergy loads of the case in the urban area as well as the total efficiency and the flexibility factors. This value is very large and proves the estimations about the residential energy consumption. This leads us to the conclusion that planners should understand and internalise energy concerns while making decisions and developing designs, since the energy demand and cost will be the prevailing cost of the building and keeping in mind the increasing price and decreasing supply of energy by fossil fuels.

Table 4 Exergy results of Mavişehir area

\begin{tabular}{lc}
\hline Exergy load winter [kW] & 9567 \\
Exergy load summer [kW] & 16,924 \\
Exergy efficiency [-] & 1.7427 \\
Exergy flexibility factor [-] & 13.14 \\
\hline
\end{tabular}

\section{Conclusion}

The selected case area is known for its high construction standards and materials, but it is seen that the buildings are not efficient in terms of energy. The positive effect of quality insulation elements, the proper orientation, and building geometry can be easily seen in some of the buildings in the exergy analysis, although there is large room for improvement in the buildings which can be seen from EFF values are in the range of $11-15 \%$ and exergy efficiency values are around $2 \%$.

When the Mavişehir 1 and Mavişehir 2 stages are compared, in general, the high-rises have similar efficiency and EFF values such as $1.5-2 \%$ in efficiencies and 10-16 in EFF values. On the other hand, the villas in Mavişehir-1 have high SEF values; since they are located in between the high-rises and the passive solar energy input is very limited. This situation decreases the efficiency of the buildings and the area. When the bad orientation and solar capacity of the villas are taken into account, the importance of energy-efficient planning and design decisions can observed easily.

Therefore, for proper energy-efficient planning and design decisions, the undertaken parameters must be taken into account in design stage and the actors in the decisionmaking process must have knowledge and sensitivity towards energy conservation and sustainability in high scale design as well as low scale and building design in the urban area.

On the other hand, the low exergy efficiency value of the total area (1.74\%) leads us to think about the importance of research about better heating and cooling systems, transmission systems, insulation materials, construction materials, and renewable energy.

When considering these results, it proves that site plan decisions and energy conservation are interrelated and essential for maximising passive system effects and minimising energy usage. Efficient use of energy and use of passive systems are key factors of sustainable urban areas. For these reasons architects, landscape architects, city planners, urban designers, and other actors that are to play a role in the construction and design of the urban area must pay attention to these topics. 
In looking at a global scale, large amounts of energy are used in buildings. For this reason, planners and architects must keep this in mind and should produce living areas that have high standards of construction. This should not only be with a luxury perspective but also from the point of view for energy efficiency. The application of this thought must start from the beginning of the design phase and continue until the project ends. This approach, with its increased efficiency, is also beneficial from an environmental perspective because it decreases the emissions that arise from the heating and cooling systems of the buildings.

Furthermore this study will continue by proposing a new exergy-efficient design of the case area, and try to make a comparison between the exergy-efficient design and the current situation, regarding efficiency, effectiveness, and sustainability issues.

\section{References}

Aydoğan, A. (2005) Residential Satisfaction in High-Rise Buildings, Master Thesis, İzmir Institute of Technology, İzmir.

Balocco, C., Papeschi, S., Grazzini, G. and Basosi, R. (2004) 'Using exergy to analyze the sustainability of an Urban area', Ecological Economics, Vol. 48, pp.231-244.

Balta, T.M., Dinçer, I. and Hepbaşl1, A. (2011) 'Development of sustainable energy options for buildings in a sustainable society', Sustainable Cities and Society, Vol. 1, pp.72-80.

Barreiro, E., Belausteguigoitia, J., Perea, E., Rodriguez, R., Romero, A. and Turienzo, E. (2009) 'City planning and energy efficiency: towards an integrated Urban design and planning process', Sustainable Development and Planning IV, Vol. 1, pp.43-51.

Depecker, P., Menezo, C., Virgone, J. and Lepers, S. (2001) 'Design of buildings shape and energetic consumption', Building and Environment, Vol. 36, pp.627-635.

Dinçer, İ. and Rosen, M. (2007) 'Exergy: Energy, environment, and sustainable development', Elsevier, pp.11-14.

Ercoşkun, Ö.Y. (2007) Sürdürülebilir Kent İçin Ekolojik-Teknolojik (Eko-Tek) Tasarım: AnkaraGüdül Örneği, PhD Thesis, Gazi University, Ankara.

Hepbaşl1, A. (2012) 'Low exergy (LowEx) heating and cooling systems for sustainable buildings and societies', Renewable and Sustaible Energy Reviews, Vol. 16, pp.73-104.

Hisarlıgil, H. (2009) Enerji Etkin Planlamada Konut Adası Tasarımı: Hipotetik Konut Adalarının Ankara Örneğinde Mikroklimatik Analizi, PhD Thesis, Gazi University, Ankara.

Institute of Energy of Turkey (2014) http://www.eie.gov.tr/verimlilik/egitim.aspx (Accessed February 2014).

Karşıyaka Municapality (2012) Department of Planning Archive, Approved plan of Mavişehir Mass Housing, Accessed on June 2012.

Koç, H. (2001) Cumhuriyet Döneminde İzmir'de Sosyal Konut ve Toplu Konut Uygulamalarl, İzmir Dokuz Eylül University Faculty of Architecture Publications, İzmir.

Koroneos, C. and Kalemakis, I. (2012) 'Exergy indicators in the building environment', International Journal of the Exergy, Vol. 11, No. 4, pp.439-459.

Liu, G., Yang, Z. and Chen, B. (2010) 'Extended exergy-based Urban ecosystem network analysis: a case study of Beijing, China', Procedia Environmental Sciences, Vol. 2, pp.243-251.

Meggers, F. and Lejbundgut, H. (2012) 'The reference environment: utilizing exergy and anergy for buildings', International Journal of the Exergy, Vol. 11, No. 4, pp.423-438.

Mert, Y. (2014) Application of Exergy Analysis Method to Energy Efficient Building Block Design, Unpublished doctoral dissertation, İzmir Institute of Technology, İzmir, Turkey. 
Network of International Society for Low Exergy Systems in Buildings (LowEx) (2012) http://www.lowex.net/ Analysis tool Accessed on September 2012.

Ozturk, H.K., Canyurt, O.E., Hepbasli, A. and Utlu, Z. (2004) 'Three different genetic algorithm approaches to the estimation of residential exergy input/ output values', Building and Environment, Vol. 39, pp.807-816.

Sakulpipatsin, P., van der Kooi, H.J., Itard, L.C.M. and Boelman, E.C. (2008) 'The influence of possible definitions of a reference environment to determine the exergy of air in buildings', International Journal of Exergy, Vol. 5, No. 3, pp.275-295.

Sayar, Y. and Süer, D. (2004) 'Küreselleşme sürecinde konut alanlarinin oluşumu ve kentsel mekana etkileri: İzmir-çiğli örneği', Mimarlık, Vol. 319, pp.76-81.

Schmidt, D. (2004) 'Design of low exergy buildings-method and a pre-design tool', The International Journal of Low Energy and Sustainable Buildings, Vol. 3, pp.1-47.

Schmidt, D. (2012) 'Benchmarking of low 'exergy' buildings', International Journal of the Exergy, Vol. 11, No. 4, pp.473-480.

Tronchin, L. and Fabbri, K. (2008) 'Analysis of buildings' energy consumption by means of exergy method', International Journal of Exergy, Vol. 5, Nos. 5-6, pp.605-625.

Turkish State Meteorological Service (MGM) (2012) http://www.mgm.gov.tr, Long term temperature report for cities, Accessed on December 2012.

Utlu, Z. and Hepbasli, A. (2005) 'Analysis of energy and exergy use of the Turkish residentialcommercial sector', Building and Environment, Vol. 4, pp.641-655.

Utlu, Z. and Hepbasli, A. (2007) 'A review on analyzing and evaluating the energy utilization', Efficiency of Countries, Renewable and Sustainable Energy Reviews, Vol. 11, pp.1-29.

\section{Website}

İzmir City Guide, İzmir Metropolitan Municipality web site, www.izmir.bel.tr (Accessed on 2012).

\section{Nomenclature}

\begin{tabular}{ll}
\hline$A$ & Area $\left(\mathrm{cm}^{2}\right)$ \\
$C_{p}$ & Specific heat $(\mathrm{kJ} / \mathrm{kgK})$ \\
$E x$ & Exergy $(\mathrm{J}, \mathrm{kJ})$ \\
$F_{f}$ & Window frame fraction \\
$g$ & Total transmittance \\
$I_{s}$ & Solar radiation $\left(\mathrm{W} / \mathrm{m}^{2}\right)$ \\
$n_{d}$ & Air exchange rate $(\mathrm{ach} / \mathrm{h})$ \\
$n_{0}$ & Number of occupants \\
$n_{v}$ & Efficiency constants \\
$T$ & Temperature $(\mathrm{K})$ \\
$t$ & Time, min \\
$U$ & Overall heat transfer coefficient $\left(\mathrm{W} / \mathrm{m}^{2} \mathrm{~K}\right)$ \\
$V$ & Volume $\left(\mathrm{m}^{3}\right)$ \\
\hline
\end{tabular}




\begin{tabular}{ll}
\hline Greek letters & \\
$\eta$ & Efficiency \\
$\Phi_{I, o}$ & Specific internal gains of occupants (W/occupant) \\
$\Phi_{I, e}$ & Specific internal gains of equipment $\left(\mathrm{W} / \mathrm{m}^{2}\right)$ \\
$\rho$ & Density $\left(\mathrm{kg} / \mathrm{m}^{3}\right)$ \\
Subscripts & \\
dest & Destruction \\
$i$ & Inner, interior \\
$o$ & Outer, exterior \\
$r e v$ & Reversible \\
$w$ & Window \\
\hline
\end{tabular}

